\title{
PERENCANAAN ASUHAN KEPERAWATAN \\ DI RUMAH SAKIT
}

\author{
Intan Faadhilah \\ Intanfaadhilah24@gmail.com
}

\section{LATAR BELAKANG}

Perencanaan adalah merupakan bagian dari fase pengorganisasian dalam proses keperawatan sebagai pedoman untuk mengarahkan tindakan keperawatan dalam usaha membantu, meringankan, memecahkan masalah. Perencanaan Keperawatan Merupakan suatu proses penyusunan berbagai intervensi keperawatan yang dibutuhkan untuk mencegah, menurunkan, atau mengurangi masalah-masalah klien. Perencanaan ini merupakan langkah ketiga dalam membuat suatu proses keperawatan. Langkah dalam tahap perencanaan ini dilakukan setelah menentukan tujuan dan kriteria hasil yang diharapkan dengan menentukan rencana tindakan apa yang akan dilaksanakan dalam mengatasi masalah klien. Dalam membuat rencana tindakan perawat harus mengetahui juga tentang instruksi atau perintah tentang tindakan keperawatan apa yang akan dilakukan dari perawat primer (pembuat asuhan keperawatan primer. Dengan proses keperawatan, rasa tanggung jawab dan tanggung gugat bagi perawat itu dapat dimiliki dan dapat digunakan dalam tindakan - tindakan yang merugikan atau menghindari adanya tindakan yang legal. Langkah ketiga dari proses keperawatan adalah (perencanaan) intervensi keperawatan. Intervensi keperawatan adalah panduan untuk peilaku spesifik yang diharapkan dari klien, dan atau tindakan yang harus dilakukan oleh perawat. Intervensi dilakukan untuk membantu klien mencapai hasil yang diharapkan. Dalam perencanaan keperawatan perawat menetapkannya berdasarkan hasil pengumpulan data dan rumusan diagnose keperawatan yang merupakan penunjuk dalam membuat tujuan dan asuhan keperawatan untuk mencegah, menurunkan atau mengeliminasi masalah kesehatan klien. Rencana keperawatan merupakan metode komunkasi tentang asuhan keperawatan kepada klien. Setiap klien memerlukan asuhan keperawatan perlu suatu perencanaan yang baik. Langkah-langkah dalam membuat perencanaan keperawatan yaitu penetapan prioritas, penetapan tujuan dan kriteria hasil yang diharapkan. Setelah diagnosa keperawatan dirumuskan secara spesifik,perawat menggunakan kemampuan berpikir kritis untuk segera menetapkan prioritas diagnose keperawatan dan intervensi yang penting sesuai dengan kebutuhan klien. 


\section{METODE}

Metode yang digunakan ialah teknik pengumpulan data atau informasi dengan melakukan analisis, eksplorasi, kajian bebas (literatur review) yang relevan yang berfokus pada bagimana menentukan tahap perencanaan dalam proses keperawatan dengan menggunakan 14 sumber referensi dari buku teks, buku referensi, jurnal, ebook yang diterbitkan 10 tahun terakhir.

\section{HASIL}

Berdasarkan hasil pencarian analisis, eksplorasi dari berbagai sumber didapatkan bahwa ada 3 elemen penting yang harus diperhatikan saat membuat perencaan keperawatan yaitu membuat prioritas masalah, menetapkan tujuan dan membuat kriteria hasil, dan merencanakan intervensi keperawatan. Buku pertama Proses keperawatan dan berpikir kritis. Deswani, 2009. Bahwa tahap perencanaan berfokus pada memprioritaskan masalah, merumuskan tujuan dan kriteria hasil, membuat intruksi keperawatan, dan mendokumentasikan rencana asuhan keperawatan. Buku kedua Konsep dasar keperawatan. Yulianingsih kodim, 2015. Dalam menentukan tahap perencaan bagi perawat diperlukan berbagai pengetahuan dan keterampilan diantaranya pengetahuan tentang kekuatan dan kelemahan klien, nilai dan kepercayaan klien,batasan praktik keperawatan, peran dari tenaga kesehatan lainnya,kemampuan dalam memecahkan masalah,mengambil keputusan, menulis tujuan serta memilih dan membuat strategi keperawatan yang aman dalam memenuhi tujuan, menulis intruksi keperawatan serta kemampuan dalam melaksanakan kerja sama dengan tingkat kesehatan lain. Buku ketiga Kebutuhan dasar manusia dan proses keperawatan. Tarwoto \& Wartonah,2010. Pada tahap perencaan keperawatan ada 4 hal yang harus diperhatikan yaitu menentukan prioritas masalah, menentukan tujuan, menentukan kriteria hasil, dan merumuskan intervensi dan aktivitas perawatan. Buku keempat Proses keperawatan dan pemeriksaan fisik. Oda Debora, 2011. Perencanaan tindakan keperawatan adalah tulisan yang dibuat dan digunakan sebagai panduan saat melakukan tindakan keperawatan untuk mengatasi masalah yang muncul. Ada 4 elemen penting yang harus diperhatikan saat membuat perencaan keperawatan yaitu membuat prioritas, menetapkan tujuan dan membuat kriteria hasilnya, merencanakan intervensi keperawatan yang akan diberikan, dan pendokumentasian. Tujuan rencana asuhan keperawatan yaitu tujuan administrasi meliputi mengidentifikasi fokus keperawatan individu atau keluarga, membedakan tanggung jawab perawat dengan profesi kesehatan lainnya, menyusun kriteria guna pengulangan asuhan 
keperawatan dan evaluasi, keberhasilan asuhan keperawatan, menyediakan kriteria klasifikasi klien, sedangkan tujuan klinik meliputi suatu pedoman dalam penulisan, mengkomunikasikan asuhan keperawatan yang akan diimplememtasikan dengan perawat lain seperti apa yang akan diajarkan, apa yang harus diobservasi, apa yang akan dilakukan. Menyusun kriteria hasil (outcome) guna pengulangan asuhan keperawatan dan evaluasi keberhasilan asuhan keperawatan, rencana intervensi yang spesifik dan langsung bagi perawat untuk melaksanakan intervensi kepada klien dan keluarganya (Cafenito,2006).

\section{PEMBAHASAN}

Proses keperawatan adalah metode dimana suatu konsep diterapkan dalam praktik keperawatan. Hal ini bisa disebut sebagai suatu pendekatan problem-solving yang memerlukan ilmu, teknik, dan ketrampilan interpersonal dan ditujukan untuk memenuhi kebutuhan klien/ keluarga. Proses keperawatan terdiri dari lima tahap yang sequensial dan berhubungan. Antara lain yaitu pengkajian, diagnosis, perencanaan, pelaksanaan, dan evaluasi. Tahap tersebut berintegrasi dalam mendefinisikan suatu tindakan perawatan. Salah satunya adalah implementasi atau pelaksanaan. Proses keperawatan menyediakan struktur bagian praktis dengan penggunaan pengetahuan dan keterampilan yang dilakukan oleh perawat untuk mengekspresikankebutuhan perawatan (human caring). Keperawatan digunakan secara terus-menerus ketika merencanakan dan memberikan asuhan keperawatan dengan mempertimbangkan pasien sebagai figur central dalam merencanakan asuhan dengan mengobservasi respons pasien terhadap setiap tindakan sebagai penatalaksanaan dalam suatu asuhankeperawatan.Pada saat implementasi perawat harus melaksanakan hasil dari rencana keperawatan yang di lihat dari diagnosa keperawatan. Pada saat implementasi perawat harus melaksanakan hasil dari rencana keperawatan yang di lihat dari diagnosa keperawatan. Di mana perawat membantu klien dari masalah status kesehatan yang dihadapi kestatus kesehatan yang lebih baik yang menggambarkan kriteria hasil yang diharapkan. Implementasi keperawatan adalah serangkaian kegiatan yang dilakukan oleh perawat untuk membantu klien dari masalah status kesehatan yang dihadapi kestatus kesehatan yang lebih baik yang menggambarkan kriteria hasil yang diharapkan. Implementasi merupakan inisiatif dari rencana tindakan untuk mencapai tujuan yang spesifik. Tahap pelaksanaan dimulai setelah rencana tindakan disusun dan ditujukan pada nursing orders untuk membantu klien mencapai tujuan yang diharapkan. Oleh karena itu rencana tindakan yang spesifik dilaksanakan untuk memodifikasi faktor-faktor yang mempengaruhi masalah kesehatan klien. Tipe implementasi keperawatan Secara garis besar terdapat tiga kategori dari implementasi keperawatan (Craven 
dan Hirnle, 2000) antara lain: a. Cognitive implementations yaitu Meliputi pengajaran atau pendidikan, menghubungkan tingkat pengetahuan klien dengan kegiatan hidup sehari-hari, membuat strategi untuk klien dengan disfungsi komunikasi, memberikan umpan balik, mengawasi tim keperawatan, mengawasi penampilan klien dan keluarga, serta menciptakan lingkungan sesuai kebutuhan, dan lain lain. b. Interpersonal implementations yaitu Meliputi koordinasi kegiatan-kegiatan, meningkatkan pelayanan, menciptakan komunikasi terapeutik, menetapkan jadwal personal, pengungkapan perasaan, memberikan dukungan spiritual, bertindak sebagai advokasi klien, role model, dan lain lain. c. Technical implementations yaitu Meliputi pemberian perawatan kebersihan kulit, melakukan aktivitas rutin keperawatan, menemukan perubahan dari data dasar klien, mengorganisir respon klien yang abnormal, melakukan tindakan keperawatan mandiri, kolaborasi, dan rujukan, dan lain-lain. Dalam pelaksanaannya terdapat tiga jenis implementasi keperawatan, antara lain: a. Independent implementations adalah implementasi yang diprakarsai sendiri oleh perawat untuk membantu klien dalam mengatasi masalahnya sesuai dengan kebutuhan, misalnya: membantu dalam memenuhi activity daily living (ADL), memberikan perawatan diri, mengatur posisi tidur, menciptakan lingkungan yang terapeutik, memberikan dorongan motivasi, pemenuhan kebutuhan psiko-sosio-spiritual, perawatan alat invasive yang dipergunakan klien, melakukan dokumentasi, dan lain-lain. b. Interdependen/ Collaborative implementations adalah tindakan keperawatan atas dasar kerjasama sesama tim keperawatan atau dengan tim kesehatan lainnya, seperti dokter. Contohnya dalam hal pemberian obat oral, obat injeksi, infus, kateter urin, naso gastric tube (NGT), dan lain-lain. Keterkaitan dalam tindakan kerjasama ini misalnya dalam pemberian obat injeksi, jenis obat, dosis, dan efek samping merupakan tanggungjawab dokter tetapi benar obat, ketepatan jadwal pemberian, ketepatan cara pemberian, ketepatan dosis pemberian, dan ketepatan klien, serta respon klien setelah pemberian merupakan tanggung jawab dan menjadi perhatian perawat. c. Dependent implementations adalah tindakan keperawatan atas dasar rujukan dari profesi lain, seperti ahli gizi, physiotherapies, psikolog dan sebagainya, misalnya dalam hal: pemberian nutrisi pada klien sesuai dengan diit yang telah dibuat oleh ahli gizi, latihan fisik (mobilisasi fisik) sesuai dengan anjuran dari bagian fisioterapi. Ada tiga prinsip pedoman implementasi keperawatan (Haryanto,2007), yaitu : a. Mempertahankan keamanan klien dengan Keamanan merupakan focus utama dalam melakukan tindakan. Oleh karena, tindakan yang membahayakan tidak hanya dianggap sebagai pelanggaran etika standar keperawatan professional, tetapi juga merupakan suatu tindakan pelanggaran hukum yang dapat ditutut. b. Memberikan asuhan yang efektif dengan memberikan asuhan yang efektif adalah memberiakan asuhan sesuai 
dengan yang harus dilakukan semakin baik pengetahuan dan pengalaman seorang perawat, maka semakin efektif asuhan yang diberikan. c. Memberikan asuhan seefisien mungkin dengan memberikan asuhan yang efisien berarti perawat dalam memberikan asuhan dapat mengunakan waktu sebaik mungkin sehingga dapat menyelesaikan masalah kilen. Tahap Tahap Implementasi a. Tahap I: Persiapan merupakan tahap awal tindakan keperawatan ini menuntut perawat mempersiapkan segala sesuatu yang diperlukan dalam tindakan. Meliputi : Review tindakan keperawatan yang diidentifikasi pada tahap perencanaan, menganalisa pengetahuan dan ketrampilan keperawatan yang diperlukan, mengetahui komplikasi dari tindakan keperawatan yang mungkin timbul, menentukan dan mempersiapkan peralatan yang diperlukan, mempersiapkan lingkungan yang kondusif sesuai dengan tindakan, dan mengidentifikasi aspek hukum dan etik terhadap resiko dari potensi tindakan. b. Tahap II: Intervensi merupakan tahap yang berfokus pada pelaksanaan tindakan perawatan adalah kegiatan pelaksanaan tindakan dari perencanaan untuk memenuhi kebutuhan fisik dan emosional. Pendekatan ini meliputi: Independen adalah suatu kegiatan yang dilaksanakan oleh perawat tanpa petunjuk dan perintah dari dokter atau tenaga kesehatan lainnya. Tipe tindakan independen keperawatan dapat dikatagorikan menjadi 4, yaitu tindakan diagnostik, tindakan terapeutik, tindakan edukatif, dan tindakan merujuk, interdependen menjelaskan suatu kegiatan yang memelukan suatu kerjasama dengan tenaga kesehatan lainnya,misalnya tenaga sosial, ahli gizi, fisioterapi dan dokter, dan dependen ini berhubungan dengan pelaksanaan rencana tindakan medis. Tindakan tersebut menandakan suatu cara dimana tindakan medis dilaksanakan. c. Tahap III: Dokumentasi merupakan pelaksanaan tindakan keperawatan harus diikuti oleh pencatatan yang lengkap dan akurat terhadap suatu kejadian dalam proses keperawatan. Ada 3 tipe sistem pencatatan yang digunakan pada dokumentasi : Sources-Oriented records, Problem-Oriented records, dan Computer-Assissted records Menurut Wilkinson (2007) implementasi yang bisa dilakukan oleh perawat terdiri dari: a. Do (melakukan), implementasi pelaksanaan kegiatan dibagi dalam beberapa kriteria yaitu: Dependen Interventions: dilaksanakan dengan mengikuti order dari pemberi perawatan kesehatan lain, Collaborative (interdependen): interpensi yang dilaksanakan dengan professional kesehatan lainnya, dan Independent (autonomous) Intervention: intervensi dilakukan dengan melakukan nursing orders dan sering juga digabungkan dengan order dari medis b. Delegate (mendelegasikan): pelaksanaan order bisa didelegasikan hanya saja ada beberapa tanggung jawab yang perlu dicermati oleh pemberi delegasi yaitu apakah tugas tersebut tepat untuk didelegasikan, apakah komunikasi tepat dilakukan, dan apakah ada supervise atau pengecekan aktivitas yang didelegasikan. c. Record (mencatat), pencatatan 
bisa dilakukan dengan berbagai format tergantung pilihan dari setiap institusi. Metode Implementasi antara lain : (1) membantu dalam Aktivitas Kehidupan Sehari-Hari merupakan aktivitas Kehidupan Sehari-Hari (AKS) adalah aktivitas yang biasanya dilakukan sepanjang hari/normal, aktivitas tersebut menyangkut : ambulasi, makan, berpakaian, mandi, menyikat gigi, dan berhias. Kondisi yang mengakibatka kebutuhan AKS dapat bersifat akut, kronis, temporer, dan permanen. Sebagai contoh, klien pascaopratif yang tidak mampu secara mandiri menyelesaikan semua AKS, sementara terus beralih melewati periode pascaopratif, klien secara bertahap kurang bergantung pada perawat untuk menyelesaikan AKS. (2) Konseling merupakan metoda implementasi yang membantu klien menggunakan proses pemecahan masalah untuk mengenali dan menangani stres dan yang memudahkan hubungan interpersonal diantara klien, keluarga dan tim perawat kesehatan. Klien dengan diagnosa psikiatris membutuhkan terapi oleh perawat yang mempunyai keahlian dalam keperaatan psikiatris oleh pekerja social, psikiater dan psikolog. (3) Penyuluhan Digunakan menyajikan prinsip, prosedur dan teknik yang tepat tentang perawatan kesehatan untuk klien dan untuk menginformasikan klien tentang status kesehatanya. (4) Memberikan Asuhan Keperawatan Langsung untuk mencapai tujuan terapeutik klien, perawat melakukan intervensi untuk mengurangi reaksi yang merugikan dengan menggunakan tindakan pencegahan dan preventive dalam memberikan asuhan.

\section{PENUTUPAN}

Perencanaan adalah merupakan bagian dari fase pengorganisasian dalam proses keperawatan sebagai pedoman untuk mengarahkan tindakan keperawatan dalam usaha membantu, meringankan, memecahkan masalah atau untuk memenuhi kebutuhan klien.Suatu perencanaan yang tertulis dengan baik akan memberi petunjuk dan arti pada asuhan keperawatan karena perencanaan adalah sumber informasi bagi semua yang terlibat dalam asuhan keperawatan klien.

\section{REFERENSI}

Allen, V. C. (1998). Memahami Proses Keperawatan Dengan Pendekatan Latihan. Jakarta: EGC.

Asmadi. (2008). Konsep Dasar Keperawatan. Jakarta: EGC

Asmuji. 2012. Manajemen Keperawatan Konsep dan Aplikasi. Jogjakarta: Ar-Ruzz Media. 
Haryanto. 2007. Konsep Dasar Keperawatan dengan Pemetaan Konsep. Jakarta : Salemba medika.

Kemenkes RI. (2015). Profil Kesehatan Indonesia Tahun 2014. Jakarta..

Carpenito, L.J., 1999. Rencana Asuhan dan Dokumentasi Keperawatan, Diagnosa Keperawatan dan Masalah Kolaboratif Edisi 2. Jakarta: EGC

Doengos, M.E., (2000), Rencana Asuhan Keperawatan : Pedoman Untuk Perencanaan Pendokumentasian Perawatan Pasien Ed. 3

Kemenkes RI. (2015). Profil Kesehatan Indonesia Tahun 2014. Jakarta..

Kozier, Barbara. (2010). Buku Ajar Fundamental Keperawatan; Konsep, Proses dan Praktik edisi 7 Volume. Jakarta: EGC.

Simamora, R. H. (2019). Menjadi Perawat yang: CIH`HUY. Surakarta: Kekata Publisher.

Simamora, Roymond H. 2010. Komunikasi dalam Keperawatan, Ed 1 hal 210. Jember: Univesity Press.

Simamora, Roymond H. Dokumentasi Proses Keperawatan, `Ed 1 hal 144. Jember: University Press.

Simamora, Roymond H. 2008. Peran Manajer dalam Pembinaan Etika Perawat Pelakasanaan dalam Peningkatan Kualitas Pelayanan Asuhan Keperawatan: Jurnal IKESMA, Ed 4, 2.

Potter \& Perry, (2005). Buku Ajar Fundamental Keperawatan: Konsep, Proses, dan Praktik. Edisi 4. Vol 1. Jakarta: EGC.

Potter \& Perry. (2009). Fundamental of Nursing. 7 th Ed. St Louis Missouri: Elseiver Perry, A. G., \& Potter, P. A. (2009). Potter and perry's fundamentals of nursing Australian version. (J. Crips \& C. Taylor, Eds.) (3rd ed). Australian : mosby Elsevier Australia.

Potter, P.A.,\& Perry, G.A. (2010). Fundamental of nursing (Volume 2, 7th Ed.). ST. Louis: Mosby Year Book.

Potter, P. A., \& Perry, A. G., (2013). Fundamentals of nursing. (8th ed). Elsevier. 